\title{
CRÉDITO E AGRICULTURA: hipotecas rurais em Ribeirão Preto (1895-1905)
}

Credit and Agriculture: Rural Mortgages in Ribeirão Preto (1895-1905)

Renato Leite

\section{MARCONDES}

\author{
(1) rlmarcon@usp.br \\ Jefferson \\ BERTOLAI' \\ (1) jbertolai@usp.br \\ Universidade \\ de São Paulo \\ Ribeirão Preto, SP, Brasil
}

\section{RESUMO}

Para analisar o papel desempenhado pelas hipotecas no auge da economia cafeeira, o artigo propõe-se estimar seus determinantes e efeitos em Ribeirão Preto, principal comarca produtora de café no início do século XX. A partir das hipotecas efetuadas entre 1895 e 1905 e dos dados agrícolas de 1904-1905, (i) comparase o perfil dos agricultores que contrataram hipotecas com aquele dos agricultores que não o fizeram, mostrando que os primeiros apresentam maiores patrimônio, produção e produtividade; e (ii) explora-se a relação entre o patrimônio em imóveis dos agricultores e a contratação de hipotecas. A análise mostra que a contratação de hipoteca se relaciona positivamente ao patrimônio dos agricultores, conforme expectativas teóricas. A análise também propõe uma estratégia para mensurar os dois componentes previstos pela teoria: o efeito da hipoteca em aumentar o patrimônio do agricultor (denominado efeito patrimonial) e o efeito do patrimônio do agricultor na capacidade de contratação de hipoteca (denominado efeito garantia). O resultado mostra que os dois efeitos foram relevantes em Ribeirão Preto no período estudado. Em conjunto, a distribuição de crédito concentrada entre os maiores agricultores e a existência do efeito patrimonial podem ser vistas como mecanismo de concentração do patrimônio entre os agricultores.

Palavras-chave: Hipoteca, Café, Estrutura fundiária, Produtividade, Estrangeiros.

\begin{abstract}
To analyze the role played by credit instruments guaranteed by mortgages in the coffee economy boom, the article proposes to estimate their determinants and effects in Ribeirão Preto, the main coffee producing region in the early 20 th century. Based on the mortgages made between 1895 and 1905 and the census data from 190405, (i) the profile of farmers who contracted mortgages was compared to that of farmers who did not, showing that the former have greater assets, production and productivity; and (ii) the relationship between the farmers' real state and the contracting of mortgages was explored. The analysis shows that mortgage contracting positively related to the farmers' real state, according to the theoretical expectations. The analysis also proposes a strategy to measure the two components predicted by the theory: the effect of the mortgage on increasing the farmer's patrimony (called the patrimonial effect) and the effect of the farmer's equity on the ability to contract the mortgage (called the collateral effect). The result shows that both effects were relevant in Ribeirão Preto in the studied period. Together, the distribution of credit concentrated among the largest farmers and the existence of the real-state effect can be seen as a mechanism for the concentration of wealth among farmers.
\end{abstract}

Keywords: Mortgage, Coffee, Land distribution, Productivity, Foreigners. 
D esde o período colonial, a expansão econômica foi acompanhada pelo crédito, num mútuo condicionamento. O financiamento representou um instrumento importante para a expansão cafeeira no Sudeste brasileiro durante os séculos XIX e XX, juntamente com os recursos acumulados previamente em outras atividades e o reinvestimento de lucros auferidos na própria cafeicultura. Durante o século XIX, o financiamento concentrou-se, inicialmente, nas mãos de comerciantes, fazendeiros e capitalistas de modo pouco institucionalizado, posteriormente cresceu a parcela das casas comissárias ou exportadoras e, finalmente, das instituições formais de crédito, como bancos, conforme os estudos de Sweigart (1980), Saes (1986), Goldsmith (1986), Moraes (1988), Triner (2000), Hanley (2005), Teodoro (2006), Piñeiro (2007), Pires (2009), Fontanari (2011 e 2015), Faleiros (2014), Tosi et al. (2011) e Ribeiro (2015). A partir do meado desse século, o governo aprimorou a regulação desse mercado, como o registro hipotecário, e apoiou, via subsídios, a formação de bancos hipotecários, como o Banco de Crédito Real de São Paulo criado ao final do Império e o Banco de Crédito Hipotecário e Agrícola do Estado de São Paulo de 1909, conforme Saes (1986) e Hanley (2005). ${ }^{2}$

No mercado de crédito, a hipoteca ganhou aos poucos uma maior presença ao longo do século XIX, principalmente após as legislações de 1846 e 1864-1865 que criaram e aprimoraram o registro hipotecário, respectivamente. ${ }^{3}$ Ainda pouco se conhece a respeito do alcance do crédito hipotecário entre os agricultores, bem como da relação entre crédito e agricultura para o Brasil no período anterior a Primeira Grande Guerra. Assim, pretendemos destacar os efeitos desse tipo de financiamento para a atividade agrícola, limitados à comarca de Ribeirão Preto na região da ferrovia Mogiana ao norte do Estado de São Paulo (ver Mapa do Apêndice A)4.

A partir de dois corpus documentais privilegiados de informações sobre o crédito e a agricultura, o registro hipotecário entre 1895 e 1905 e o recenseamento agrícola de 1904-1905, ${ }^{5}$ o objetivo consiste em mostrar como se empregou esse tipo de crédito na agricultura de Ribeirão Preto por meio do cruzamento das duas fontes. Tentamos associar o uso desse financiamento com diferentes características agrícolas, como produção do café, estimativa do valor da propriedade e área.

Numa primeira seção, realizamos, baseados na literatura econômica, uma discussão teórica sobre a importância do crédito e das formas de solução dos problemas de assimetria de informação a ele associados, como a hipoteca com garantias reais. Posteriormente, caracterizamos as fontes e os dados da agricultura em 1904-1905 e das hipotecas em 1895-1905 da comarca de Ribeirão Preto. Mesmo restritos a um subgrupo dos agricultores, os montantes hipotecados foram expressivos relativamente ao valor estimado pelas propriedades no censo. Na terceira seção, comparamos dois subconjuntos da atividade agrícola, os que realizaram hipotecas até 10 anos antes do censo e os que não o fizeram. Desse modo, podemos evidenciar as diferenças entre os dois grupos. Ademais, analisamos em seguida apenas os agricultores que efetuaram hipoteca, distinguindo os que tomaram empréstimos de forma mais ou menos intensa e o perfil deles no censo. Por fim, na última seção, exploramos mais cuidadosamente a relação entre os valores estimados para as propriedades rurais 
em 1904-1905 e as hipotecas. A estratégia empírica nesta seção faz uso dos registros de hipotecas realizadas em Ribeirão Preto no período 1905-1914 para construir uma medida de impacto do patrimônio dos agricultores sobre a hipoteca.

\section{Hipotecas: perspectiva teórica e estratégia empírica}

A alocação eficiente de recursos de poupança entre os diferentes projetos de investimento é um importante determinante do bem estar da sociedade. O sistema de preços (mercado) é especialmente insatisfatório para organizar a alocação de poupança da economia devido à pervasividade de assimetrias de informação na relação de crédito entre poupadores e proprietários de projetos de investimento ${ }^{6}$. Como consequência, outros mecanismos são frequentemente adotados pela sociedade para organizar a alocação de poupança, dentre eles a modalidade de crédito via hipoteca.

Duas assimetrias de informação na relação de crédito são especialmente importantes. O proprietário do projeto de investimento (doravante denominado empreendedor) possui mais conhecimento sobre a qualidade de sua oportunidade de investimento do que o potencial financiador (poupador). Além disso, o comportamento do empreendedor após firmado o contrato de crédito não é perfeitamente observável pelos poupadores, o que possibilita comportamentos oportunistas prejudiciais aos credores. O típico resultado de ineficiência no primeiro tipo de assimetria de informação é conhecido como Seleção Adversa: somente projetos de investimento de baixa qualidade são transacionados em equilíbrio. No segundo tipo de assimetria, os credores antecipam eventuais comportamentos oportunistas e, por isso, estão menos dispostos a emprestar seus recursos. Este fenômeno é conhecido como Moral Hazard e, tipicamente, provoca aumento no preço (taxa de juros) de equilíbrio.

Os típicos instrumentos de enfrentamento a assimetria de informação (a oferta de um menu de opções de empréstimos e monitoramento de projetos, acompanhado de punições ao devedor em caso de detecção de oportunismo) não são inconsistentes com a organização do sistema de crédito via mercados. Mas a centralização destas atividades (a produção/coleta de informações, a concessão de crédito e o monitoramento dos projetos) no sistema bancário é uma alternativa mais socialmente mais eficiente.

Bens duráveis também podem ser (e frequentemente são) utilizados na relação de crédito como um importante instrumento para enfrentar os problemas decorrentes da existência de assimetria de informação, tanto pré-contratuais quanto pós-contratuais. Nesta modalidade de crédito, o empreendedor autoriza uma terceira parte (quase sempre, o Estado) a transferir sua propriedade sobre um dado bem durável (usualmente, um imóvel) para o credor em caso de descumprimento de cláusulas do contrato de empréstimo. Ou seja, o bem durável é usado como colateral (garantia) no contrato de empréstimo.

O potencial que a utilização de colateral possui para amenizar os problemas causados pela existência de assimetria de informação na relação de crédito depende, portanto, fundamentalmente da capacidade da terceira parte em transferir a propriedade do bem durável. A utilização simultânea do bem durável como garantia/colateral em 
poucos contratos de empréstimo é componente central para preservar tal capacidade. A complexidade do processo de transferência de propriedade de um bem durável dado em garantia para mais de um credor é bastante grande e pode inviabilizar a utilização de colateral em relações de crédito.

Segue do exposto que é bastante importante para o credor, no momento de celebração de um dado contrato de empréstimo, saber a quantidade de vezes que o bem durável a ele prometido como colateral estará prometido para outros credores durante a vigência de seu contrato. Para esta necessidade, a centralização da coleta e manutenção de tais informações em um único agente (frequentemente um cartório) emerge como a solução natural, desde que as informações sejam compartilhadas com os credores interessados. Este agente garantiria publicidade tanto do registro de propriedade do bem durável quanto do registro dos contratos de empréstimo nos quais o bem foi usado como colateral.

A relação de crédito denominada hipoteca é um caso particular de crédito com colateral. Nesta modalidade de crédito, um bem imóvel é usado como garantia/colateral e a terceira parte designada para transferir a propriedade-garantia é o sistema judiciário. Em caso de descumprimento de cláusulas contratuais por parte do empreendedor, os credores acionam o judiciário para executar a hipoteca (transferir a propriedade do colateral/imóvel). Para este caso, a publicidade das hipotecas por meio de seu registro favorece a sua utilização, uma vez que reduz o problema de assimetria de informação. A partir do registro, todos podem saber quem fez hipoteca e qual o valor desse financiamento, que compromete determinadas propriedades colateralizadas.

A oferta de recursos por meio de contratos de hipoteca, portanto, depende diretamente do valor de mercado do imóvel dado em garantia e da capacidade do sistema judiciário garantir a transferência da propriedade utilizada como colateral em caso de não pagamento do empréstimo. Se o valor do imóvel é alto e o Judiciário possui facilidade/agilidade para executar a hipoteca, o montante de crédito ofertado via hipoteca do referido imóvel será alto e a taxa de juros cobrada será menor. Se o valor do imóvel é baixo e o Judiciário enfrenta dificuldades para (ou se recusa a) executar a hipoteca, o montante de crédito ofertado via hipoteca será baixo e a taxa de juros será alta. Em particular, o credor não aceitará imóveis de baixo valor como garantia em contratos de hipoteca se este antecipa um custo fixo relevante para avaliar, monitorar e executar a hipoteca.

Conforme discutido acima, o sistema de crédito resolve um importante problema de alocação de recursos: o descasamento entre disponibilidade de poupança e acesso a projetos de investimentos. Ao melhorar a canalização de poupança para bons projetos de investimento, o crédito melhora tanto a situação dos poupadores quanto a situação dos empreendedores. Neste sentido, é razoável esperar que a existência de linhas de crédito promova o consumo e o investimento (ou poupança) destes agentes. Como consequência, espera-se um efeito positivo do acesso ao crédito no patrimônio dos poupadores e dos empreendedores.

A modalidade de crédito via hipotecas, em particular, interage com o patrimônio dos empreendedores também na direção oposta: o volume de crédito contratado via 
hipoteca depende positivamente do patrimônio do empreendedor. Empreendedores com maior patrimônio imóvel possuem maior capacidade de oferta de garantias ao credor e, portanto, possuem melhor acesso a crédito via hipoteca. Tal dependência positiva é bastante relevante quando o patrimônio do empreendedor é reduzido. Se o patrimônio não é suficiente para viabilizar o montante de crédito desejado pelo empreendedor, todo o patrimônio será usado como garantia para tomar emprestado o máximo possível de recursos. Se o patrimônio já é suficiente para viabilizar o montante de crédito desejado, aumentos no patrimônio não afetam o montante de crédito contratado via hipoteca. ${ }^{7}$

Com base nas considerações analíticas expostas, é esperado observar nos dados: (i) correlação positiva entre o patrimônio do empreendedor e o volume de crédito via hipotecas por ele contratado e; (ii) redução desta correlação para níveis mais elevados de patrimônio. O efeito do patrimônio do empreendedor no volume de crédito acessado (doravante denominado efeito garantia) se manifestaria em correlação positiva e contemporânea: maior volume de crédito tomado pelos empreendedores com mais patrimônio no momento da contratação da hipoteca. Por outro lado, o efeito do acesso a hipotecas sobre o patrimônio do empreendedor (doravante denominado efeito patrimonial) se manifestaria em correlação positiva e intertemporal: maior patrimônio acumulado por empreendedores que acessaram crédito via hipoteca em períodos anteriores.

A identificação de cada um dos dois tipos de correlação é uma tarefa não trivial. Dois fatores, a característica de alta durabilidade de bens imóveis e a baixa frequência com que tais bens são transacionados, implicam mecanicamente alta correlação intertemporal para o patrimônio do empreendedor. Ou seja, o montante de patrimônio é bastante persistente no tempo. Assim, mesmo sob ausência do efeito patrimonial, é possível observar correlação positiva intertemporal entre volume de hipotecas realizadas em um período com o patrimônio do empreendedor em períodos futuros ${ }^{8}$. Bastaria a existência do efeito garantia e alta persistência do patrimônio.

Idealmente, a análise empírica seria dividida em duas partes: (i) identificaria o efeito garantia estudando a correlação contemporânea entre o volume de crédito contratado via hipoteca e o estoque de patrimônio do empreendedor; e (ii) identificaria o efeito patrimonial estudando a correlação intertemporal entre o volume de crédito via hipotecas e a variação de patrimônio do empreendedor nos períodos seguintes. No entanto, a natureza do trabalho com dados históricos limita o alcance da análise empírica. No presente trabalho, em particular, há informação sobre o patrimônio dos empreendedores rurais (doravante agricultores) somente para o ano agrícola de 19041905 e há informações sobre contratos de hipotecas desde o final do Império. A partir de tal restrição, a estratégia empírica foi composta de dois exercícios: (i) estudar a correlação do patrimônio de 1904-1905 com as hipotecas contratadas nos 10 anos anteriores e; (ii) estudar a correlação do patrimônio de 1904-1905 com as hipotecas contratadas nos 10 anos posteriores. A escolha de dez anos é explicada na próxima seção, em face dos prazos dos empréstimos. 
Se a correlação intertemporal do patrimônio é de fato alta, o dado disponível para 1904-1905 é uma boa medida do patrimônio dos agricultores no período 1895-1914. Se o patrimônio possui baixa persistência, por outro lado, a medida para 1904-1905 guarda pouca relação com o patrimônio no período 1895-1914. Assim, correlação positiva nos exercícios (i) e (ii) deve ser vista como indício de que há persistência patrimonial e de que o volume de crédito via hipoteca depende positivamente do patrimônio do agricultor (efeito garantia). Correlação positiva no exercício (i), no entanto, é qualitativamente distinta de correlação positiva no exercício (ii) no que se refere ao efeito patrimonial. Enquanto é natural imaginar que correlação positiva no exercício (i) reflete também o efeito patrimonial, uma vez que a medida de hipoteca é anterior a medida de patrimônio, é difícil conceber que tal efeito se faça presente na correlação positiva do exercício (ii), no qual a medida de patrimônio é anterior ao dado de hipoteca.

Com base neste argumento, a diferença entre a correlação do exercício (i) e a correlação do exercício (ii) é eleita como a medida deste estudo para o efeito patrimonial. O efeito garantia, por sua vez, será mensurado pela correlação positiva do exercício (ii).

\section{Fontes e análise dos dados}

Antes de analisar os resultados da estratégia empírica para identificar os efeitos patrimônio e garantia, esta seção apresenta uma análise descritiva dos dados. Na primeira parte desta realizamos uma análise em separado das duas fontes de dados. Posteriormente, apresentamos o perfil dos agricultores divididos em dois grupos, que fizeram ou não hipotecas. Por fim, procura-se verificar a mudança de características dos agricultores em função do valor hipotecado. Primeiramente, no entanto, caracterizamos as fontes de dados e os métodos utilizados.

As nossas informações para os proprietários agrícolas basearam-se no censo de 1904-1905 e para os devedores de hipotecas rurais extraímos do registro hipotecário da comarca entre 1895-1905. O censo agrícola apresenta microdados para os agricultores do Estado de São Paulo naquele ano agrícola, oferecendo um conjunto amplo de dados, incluindo o nome, nacionalidade, área (total, cultivada, mata e com café), produção agrícola, pés de café, animais, valor do solo por alqueire, valor total da propriedade e número de trabalhadores (nacionais e estrangeiros). ${ }^{9}$ Apesar do valor do solo por alqueire ter menor variabilidade, o valor da propriedade mostrou maior dispersão não apenas em função da dimensão em área do estabelecimento. ${ }^{10}$

O registro de hipotecas fornece o nome, profissão e moradia do credor e devedor, bem como valor, prazo, juros e garantias dos empréstimos. Depois do pagamento havia a baixa da hipoteca. Tal documentação permite uma caracterização do crédito hipotecário por pessoa, seja credor ou devedor. Utilizamos as informações agrícolas e de crédito dos devedores para realizar o cruzamento de dados das duas fontes. Assim, a unidade de análise estabelecida foi a pessoa e não os estabelecimentos, mas quando necessário destacamos os casos de pessoas que detêm mais de uma propriedade. ${ }^{11}$ 
No presente trabalho, há informação sobre a produção e o patrimônio dos empreendedores rurais (doravante agricultores) somente para o ano agrícola de 19041905, mas para os contratos de hipotecas desde o período do final do Império. Como veremos adiante, o prazo médio das hipotecas alcançou pouco mais de dois anos, porém houve grande variância, chegando a mais de dez anos para os empréstimos externos. Assim, definimos, por hipótese, o prazo de dez anos, como suficiente para abarcar a quase totalidade das hipotecas em vigor em 1904-1905. Por outro lado, existiram casos de empréstimos de menores prazos iniciados nos primeiros anos do período 1895-1905 que já deveriam ter sido encerrados em 1904-1905 e computamos nessa seleção, superestimando esses casos na amostra escolhida de dez anos. Apesar desse problema e de certa arbitrariedade na escolha do período, preferimos um intervalo maior para evitar que empréstimos mais a longo prazo fossem excluídos.

\section{Agricultura e as hipotecas em Ribeirão Preto}

Embora Ribeirão Preto fosse um município recente no início do século $X X$, ele apresentou um rápido crescimento econômico e demográfico com a chegada do cafeeiro, da ferrovia e dos imigrantes nacionais e estrangeiros ${ }^{12}$. Nesses anos, a produção de café cresceu de forma extraordinária. Como evidência disto, a comarca de Ribeirão Preto efetuou a cobrança do imposto sobre o café colhido no início da República, tributando 113 cafeicultores ao redor de $1890^{13}$. Se nesse momento a colheita atingiu 260 mil arrobas, já no censo de 1904-1905, a comarca de Ribeirão Preto detinha a maior produção de café do Estado de São Paulo, atingindo quase 3,5 milhões de arrobas por meio de 450 produtores. Dos 113 cafeicultores do início da República, conseguimos localizar 36 em 1904-1905. Eles colhiam 137 mil arrobas no primeiro momento e, depois de cerca de quinze anos, produziram mais de um milhão de arrobas. Assim, não apenas a comarca passou a produzir mais café, mas também os produtores alcançaram portes mais avantajados. O crédito e, em particular, o hipotecário constituiu um elemento importante para o boom extraordinário da preciosa rubiácea na comarca.

Como pode ser visto na Tabela 1, a colheita em 1904-1905 do principal produto da comarca derivava da utilização de pouco mais de vinte e oito mil alqueires de terras apenas com cafezais. Esta cultura ocupou a grande maioria das áreas cultivadas (99,3\%), constituindo um “mar” de café. As áreas de plantio da preciosa rubiácea consorciavam-se às de cultivo de milho, feijão e arroz, que alcançavam mais de dois terços da área cafeicultora ${ }^{14}$. Havia grande área em pastos e campos para a criação de animais ${ }^{15}$. Os 51 milhões de pés de café distribuíram-se na proporção de quase dois mil para cada alqueire de terra. A produtividade do café alcançou quase 67 arrobas por mil pés, representando um patamar bastante expressivo comparativamente a outros municípios do Estado. 
Tabela 1 - Proprietários rurais segundo nacionalidade (1904-1905)

\begin{tabular}{lccccccc}
\hline \multirow{2}{*}{ Nacionalidade } & $\mathbf{n}^{\circ}$ & \multicolumn{2}{c}{ Área em alqueires } & \multicolumn{2}{c}{ Café } & \multicolumn{2}{c}{ Trabalhador Propriedades } \\
\cline { 2 - 7 } & & Total & Café & Pés & Arrobas & $\mathbf{n}^{\circ}$ & Contos Réis \\
\hline Alemão & 4 & 10.329 & 3.365 & 6.465 .500 & 427.700 & 3.906 & 17.221 \\
Austríaco & 20 & 136 & 110 & 217.355 & 7.260 & 113 & 188 \\
Brasileiro & 360 & 79.961 & 21.049 & 38.158 .129 & 2.574 .986 & 24.363 & 60.617 \\
Espanhol & 1 & 3 & 2 & 3.000 & 150 & 1 & 3 \\
Francês & 2 & 385 & 75 & 129.000 & 8.000 & 61 & 270 \\
Inglês & 1 & 12.000 & 2.216 & 3.999 .990 & 310.000 & 3.008 & 3.500 \\
Italiano & 139 & 3.433 & 984 & 1.849 .000 & 106.776 & 1.134 & 2.687 \\
Português & 41 & 1.585 & 558 & 1.023 .600 & 56.600 & 603 & 1.443 \\
Total & 568 & 107.768 & 28.329 & 51.778 .574 & 3.487 .472 & 33.189 & 85.869 \\
\hline
\end{tabular}

Fonte: Estatística Agrícola e Zootécnica de 1904-1905.

Nota: $O$ valor das propriedades foi estimado no próprio censo a partir de um valor estipulado para o alqueire de terra e as benfeitorias, plantações e animais de cada propriedade.

O número total de propriedades agrícolas chegou a 620 , porém eram possuídas por 568 pessoas ou instituições. A diferença decorreu de um pequeno subgrupo de grandes proprietários, que muitas vezes possuíam mais de uma propriedade na comarca. O alemão Francisco Schmidt representou o caso mais emblemático, além de ser o maior cafeicultor. Os seus 25 estabelecimentos compreenderam quase dez mil alqueires de terras. Ele detinha quase seis milhões pés de café cuidados por 3.753 trabalhadores e que produziram 406 mil arrobas. A aquisição de diversas propriedades permitiu a formação de uma gigantesca capacidade produtiva sob seu controle, apoiado comercialmente e financeiramente pela casa exportadora Theodor Wille, conforme Moraes (1988). Outros 22 cafeicultores detinham mais de uma propriedade: dois possuíam quatro, dois detinham três e os demais mantinham duas.

A companhia inglesa Dumont representava a segunda maior produtora com quatro milhões de pés em apenas uma propriedade gigante já adquirida praticamente desse tamanho, colhendo 310 mil arrobas por meio dos seus três mil trabalhadores. A área total da companhia superou em muito à do alemão, perfazendo doze mil alqueires. Apesar dos dois casos mais emblemáticos dos maiores produtores e estrangeiros, a maioria dos nascidos no exterior apresentava propriedades menores do que a média.

A nacionalidade pode informar o momento da imigração para a região, pois a imigração estrangeira era mais limitada até o final do Império, principalmente de portugueses, crescendo posteriormente, como dos italianos. Os 360 brasileiros possuíam em média 222 alqueires de terras, dos quais 59 cultivados com a preciosa rubiácea. Eles detinham em média 106 mil pés de café, em que colhiam em média pouco mais de sete mil arrobas. O número médio de trabalhadores chegou a 68. De outro lado, os italianos constituíam o segundo grupo mais numeroso, compreendendo 139 proprietários. A área média deles mostrou-se muito menor, atingindo 24 alqueires de área total e sete com cafeeiros, demonstrando que a maioria detinha poucos recursos relativamente aos brasileiros. $O$ intenso fluxo imigratório recente desse contingente para a região a partir do final da década de 1880 refletiu no expressivo número de 
proprietários de pequenas e médias propriedades. Os 41 agricultores portugueses formavam o terceiro grupo mais numeroso, mas com área média superior à dos italianos: 39 alqueires. A imigração portuguesa cresceu nessa época, mas já ocorria a bastante tempo para o Brasil. Por fim, os do Império Austro-húngaro somaram apenas 20 pessoas, que possuíam uma área média de apenas sete alqueires. Desse modo, os portugueses derivavam de um movimento imigratório mais antigo e conseguiram alcançar propriedades maiores que os italianos e principalmente os austro-húngaros.

O rápido crescimento do plantio de cafezais demandou investimentos expressivos, que foram parcialmente financiados por meio do crédito, dos quais o hipotecário constituiu uma das opções. ${ }^{17}$ Nos concentramos nesse último tipo de financiamento. As hipotecas rurais ocorridas entre 1895 e 1905 compreenderam 922 registros e totalizaram mais de cem mil contos de réis, como pode ser visto na Tabela 2 . Um valor bastante expressivo, tendo em vista que superara o valor de todas as propriedades agrícolas em 1904-1905, estimado em pouco mais de 85.000 contos de réis. Apenas os financiamentos dos dois maiores cafeicultores somaram mais de um terço do total $(38,8 \%)$. A companhia Dumont, por exemplo, foi incorporada pelos ingleses e fez grandes financiamentos em 1895 e 1896, até mesmo por debentures. Seus três empréstimos hipotecários totalizaram cerca de 27 mil contos de réis (como visto na primeira linha da Tabela 2 a seguir), apesar do valor da propriedade em 1904-1905 ser estimado em apenas 3,5 mil contos de réis. A companhia passava por uma mudança de controle e se financiou a longo prazo, em média quase 14 anos, não realizando hipoteca posteriormente. Mesmo não considerando os dois maiores cafeicultores, as 912 hipotecas ainda somavam 64 mil contos de réis em empréstimos, enquanto o valor estimado de todas as propriedades alcançava um valor próximo. Destarte, a movimentação financeira foi muito intensa nesse período, não apenas para os maiores cafeicultores. De modo semelhante, a área negociada nas hipotecas suplantou a própria área do município, alcançando 131 mil alqueires. As transações com as mesmas propriedades repetiam-se multiplicando os negócios.

Tabela 2 - Hipotecas rurais segundo moradia do devedor (1895-1905)

\begin{tabular}{lccccc}
\hline Moradia & $\mathbf{n}^{\mathbf{0}}$ & Valor & Prazo médio & Juros médio & Alqueires \\
\hline Exterior & 3 & 26.864 & 163,5 & $5,7 \%$ & 7.270 \\
Interior de São Paulo & 65 & 6.526 & 44,3 & $11,2 \%$ & 4.658 \\
Ribeirão Preto & 782 & 50.974 & 26,1 & $14,7 \%$ & 68.491 \\
Rio de Janeiro & 3 & 578 & 36,0 & $10,0 \%$ & 1.900 \\
Santos & 5 & 560 & 25,6 & $9,2 \%$ & 566 \\
São Paulo capital & 38 & 16.950 & 46,7 & $10,6 \%$ & 46.788 \\
Não identificado & 26 & 2.613 & 31,7 & $14,3 \%$ & 1.749 \\
\hline Total & 922 & 105.064 & 28,9 & $14,2 \%$ & 131.422 \\
\hline
\end{tabular}

Fonte: Primeiro Cartório de Registro de Imóveis de Ribeirão Preto.

Nota: Valor em contos de réis, prazo em meses e juros em porcentagem ao ano. 
A grande maioria dos devedores morava em Ribeirão Preto, dentre eles Francisco Schmidt. Mais de quatro quintos do número das hipotecas foram realizadas pelos moradores do município (84,8\%), porém apenas $48,5 \%$ do valor. A companhia Dumont fez as três transações no exterior, que responderam por um quarto das quantias negociadas (25,6\%). A família Prado residia na capital paulista, mas detinha grandes propriedades no município ${ }^{18}$. Desse modo, o elevado valor hipotecado pelos moradores da capital perfez cerca de um sexto do total (16,1\%). Ademais, não havia grande representatividade dos montantes dos residentes no Rio de Janeiro e Santos, apenas os do interior de São Paulo (6,2\%).

Para o conjunto de todas as hipotecas de 1895 a 1905, o valor médio emprestado chegou a 114 contos de réis, o que consistia em um valor expressivo para a época ${ }^{19}$. No censo agrícola de 1904-1905, as propriedades de valor estimado igual a 120 contos detinham, em média, cerca de 200 alqueires e 90 mil pés de café. De outro lado, para o conjunto das hipotecas, a taxa de juros média anual atingiu 14,2\% e o prazo médio 28,9 meses. A companhia Dumont detinha as condições mais favoráveis de financiamento, possivelmente por acessar o crédito externo com maior facilidade. Já em condições muito menos favorável, verificamos os devedores que moravam na capital e no interior do Estado, sem considerar Ribeirão Preto. O crédito local mostrou-se o menos favorecido, relativamente os demais: 26,1 meses de prazo em média e $14,7 \%$ de taxa de juros média anual. Como esperado, a correlação entre o valor hipotecado e as condições dos empréstimos mostrou-se significativa, mas com coeficientes bastante reduzidos: 0,207 para o prazo e -0,102 para a taxa de juros. Desse modo, os maiores emprestadores conseguiam prazos maiores e juros menores do que os menores tomadores de crédito $^{20}$.

\section{Agricultores com e sem hipoteca}

De início, selecionamos os agricultores do censo de 1904-1905 que realizaram hipotecas nos dez anos anteriores. Conseguimos localizar pelo menos uma hipoteca entre 1895 e 1905 para 145 agricultores. Assim, pudemos dividir os proprietários rurais do censo em dois grupos ${ }^{21}$. O primeiro foi identificado como tendo efetuado hipoteca e o outro grupo daqueles que não o fizeram. A Tabela 3 apresenta o perfil de cada um dos dois grupos. O agrupamento que efetuou hipoteca consistia em pouco menos de um terço dos proprietários e cafeicultores. A prevalência de mulheres ocorria na mesma proporção dos indicadores anteriores, porém com relação às companhias a ocorrência mostrou-se superior entre os que fizeram hipoteca e inferior para estrangeiros. Entre esses últimos, os italianos detinham menor representação, refletindo a menor disponibilidade de recursos, a chegada mais recente e, talvez, alguma dificuldade de obter financiamento hipotecário, pois dependia da posse de uma propriedade. As companhias conseguiam fazer mais hipotecas, pois reuniam com maior facilidade capitais.

Os proprietários que realizaram hipotecas detinham pouco mais de dois terços da área total, dos trabalhadores, do valor das propriedades, dos pés e da produção de café. A área total média, cafezal médio e o número médio de trabalhadores por 
Tabela 3 - Agricultores em 1904-05 e hipotecas em 1895-1905

\begin{tabular}{|c|c|c|c|c|c|}
\hline \multirow[b]{2}{*}{ Característica } & \multicolumn{5}{|c|}{ Realizou Hipoteca } \\
\hline & $\operatorname{sim}$ & $\%$ & Não & $\%$ & $\begin{array}{c}\text { Todos os } \\
\text { proprietários }\end{array}$ \\
\hline Proprietários & 145 & 25,5 & 423 & 74,5 & 568 \\
\hline Cafeicultores & 135 & 30,0 & 315 & 70,0 & 450 \\
\hline Mulheres & 7 & 25,9 & 27 & 74,1 & 27 \\
\hline Companhia & 9 & 37,5 & 15 & 62,5 & 24 \\
\hline Italianos & 20 & 14,4 & 119 & 85,6 & 139 \\
\hline Portugueses & 10 & 24,4 & 31 & 75,6 & 41 \\
\hline Brasileiros & 109 & 30,3 & 251 & 69,7 & 360 \\
\hline área total* & 77.149 & 71,5 & 30.683 & 28,5 & 107.832 \\
\hline Pés de café & 35.632 .596 & 68,7 & 16.212 .978 & 31,3 & 51.845 .574 \\
\hline Produção de café** & 2.498 .786 & 71,7 & 992.686 & 28,3 & 3.491 .472 \\
\hline Trabalhadores & 22.792 & 68,6 & 10.429 & 31,4 & 33.221 \\
\hline Valor das propriedades ${ }^{* * *}$ & 63.022 & 73,3 & 22.907 & 26,7 & 85.929 \\
\hline área total média* & 532 & & 73 & & 190 \\
\hline Média de trabalhadores & 157 & & 25 & & 59 \\
\hline Cafezal médio ${ }^{\dagger}$ & 245.742 & & 38.329 & & 91.277 \\
\hline Produção por mil pés** & 70,1 & & 61,2 & & 67,3 \\
\hline Produção por tabalhador** & 109,6 & & 95,1 & & 105,1 \\
\hline Valor por trabalhador & 2,8 & & 2,2 & & 2,6 \\
\hline
\end{tabular}

Fonte: Primeiro Cartório do Registro de Imóveis e Estatística Agrícola e Zootécnica de 1904-1905.

Notas: *área em alqueires. ** produção de café em arrobas. ${ }^{* * *}$ valor em contos de réis. †pés de café.

proprietário alcançavam um patamar cerca de seis ou sete vezes maior para os que realizaram hipoteca do que os que não o fizeram. De outro lado, o grupo que não fez hipoteca era mais numeroso, mas detinha menos recursos e produzia menos café. Por fim, a comparação mais interessante relacionou-se aos indicadores de produtividade. Os agricultores do primeiro grupo apresentavam índices de produção por mil pés e por trabalhador ligeiramente superiores, em cerca de um sétimo maior. O valor da propriedade por trabalhador mostrou-se superior para quem efetuou hipoteca. Outrossim, isto sugere para maiores investimentos financiados pela hipoteca, permitindo propriedades maiores e que alcançavam valores superiores.

Os tomadores de hipoteca constituíam uma parcela muito menor dos agricultores do município, mas respondiam por grande parte dos recursos produtivos e da colheita de café. Tal fato decorreu do maior porte desses proprietários, conforme documentado na Tabela 4. Em todas as faixas de tamanho de propriedades verificamos agricultores que não negociaram hipoteca nos dez anos anterior ao censo, sendo que apenas 
Tabela 4 - Agricultores com hipoteca por faixas de tamanho das propriedades (1895-1905)

\begin{tabular}{lcccccc}
\hline $\begin{array}{l}\text { Faixa de } \\
\text { tamanho }\end{array}$ & \multicolumn{3}{c}{ Realizaram Hipoteca } & \multicolumn{3}{c}{ Todos proprietários } \\
\cline { 2 - 7 } & $\mathbf{N}^{\circ}$ & $\%$ & $\begin{array}{c}\text { área } \\
\text { (alqueires) }\end{array}$ & $\%$ & $\mathbf{N}^{\circ}$ & $\begin{array}{c}\text { área } \\
\text { (alqueires) }\end{array}$ \\
\hline 1 a 10 & 23 & 10,1 & 119 & 9,1 & 227 & 1.309 \\
11 a 25 & 23 & 21,7 & 354 & 19,8 & 106 & 1.786 \\
26 a 50 & 17 & 29,8 & 683 & 31,3 & 57 & 2.184 \\
51 a 100 & 19 & 33,3 & 1.522 & 35,0 & 57 & 4.354 \\
101 a 500 & 40 & 44,9 & 8.095 & 43,7 & 89 & 18.508 \\
501 a 1.000 & 8 & 57,1 & 5.517 & 55,2 & 14 & 9.989 \\
1.001 ou mais & 15 & 83,3 & 60.859 & 87,3 & 18 & 69.703 \\
\hline Total & 145 & 25,5 & 77.149 & 71,5 & 568 & 107.769 \\
\hline
\end{tabular}

Fonte: Primeiro Cartório do Registro de Imóveis e Estatística Agrícola e Zootécnica de 1904-1905.

um décimo dos agricultores realizou empréstimo hipotecário na primeira faixa de tamanho, enquanto que tal porcentual chegou a mais de quatro quintos na última faixa, principalmente em termos da área das propriedades. O tamanho médio daqueles que efetuaram hipoteca foi de 532 alqueires, mais de duas vezes superior à da totalidade dos agricultores do censo (190 alqueires). Assim, a hipoteca não era contratada por todos os agricultores, mesmo dentre os grandes. Mas estes últimos encontravam-se mais representados nessas operações de financiamento.

A desigualdade de contratação de crédito hipotecário mostrou-se bastante expressiva, já que muito poucos dos pequenos o obtiveram. De outro lado, a grande maioria dos maiores proprietários contrataram esse tipo de financiamento. Destarte, o emprego da hipoteca nessa região e momento revelou-se uma forma bastante desigual de empréstimo, ampliando a diferença de recursos produtivos entre os agricultores.

\section{Agricultores e o montante hipotecado}

Apesar de poucos agricultores conseguirem empréstimo hipotecário, ainda precisamos saber qual o efeito desse financiamento para esse subgrupo. $O$ valor hipotecado correlacionou-se expressivamente às variáveis de recursos produtivos, como área, produção de café e número de trabalhadores ${ }^{22}$. Há uma grande desigualdade dos montantes emprestados, como pode ser observado na Tabela 5. Os recursos financiados tenderam a variar de acordo com o porte do agricultor, num mútuo condicionamento que sugere a presença simultânea dos efeitos garantia e patrimonial. Os proprietários que realizaram hipotecas de até 19 contos de réis entre 1895 a 1905, representavam quase um terço do total. Contudo, eles detinham apenas meio ponto porcentual dos valores hipotecados totais e parcela um pouco maior da área total e da produção de café. Por fim, havia entre eles a maioria dos italianos que realizaram hipoteca.

No outro extremo, verificamos os proprietários que transacionaram 200 ou mais contos de réis em hipotecas entre 1895 e 1905. Embora representassem menos de 
Tabela 5 - Proprietários rurais segundo faixa de valor da hipoteca

\begin{tabular}{lccccccccc}
\hline Faixa de valor* & $\mathbf{N}^{\circ}$ & $\%$ & valor* $^{*}$ & $\%$ & área** $^{*}$ & $\%$ & producão*** & $\%$ & Italianos \\
\hline até 19 & 48 & 33,1 & 374 & 0,5 & 1.542 & 2,0 & 66.410 & 2,7 & 12 \\
20 a 199 & 55 & 37,9 & 4.807 & 6,1 & 11.274 & 14,6 & 465.120 & 18,6 & 8 \\
200 ou mais & 42 & 29,0 & 73.166 & 93,4 & 64.333 & 83,4 & 1.967 .256 & 78,7 & 0 \\
\hline Total & 145 & 100,0 & 78.346 & 100,0 & 77.149 & 100,0 & 2.498 .786 & 100,0 & 20 \\
\hline
\end{tabular}

Fonte: Primeiro Cartório do Registro de Imóveis e Estatística Agrícola e Zootécnica de 1904-1905.

Notas: ${ }^{*}$ em contos de réis, ${ }^{* *}$ em alqueires, ${ }^{* * *}$ em arrobas.

um terço do total, eles responderam por mais de nove décimos dos valores totais hipotecados e cerca de quatro quintos da área e da produção de café. Nenhum deles era italiano. Assim, havia uma concentração dos recursos creditícios nas mãos dos maiores proprietários.

Os financiamentos hipotecários permitiram a mobilização dos fatores produtivos, como terra e trabalhadores. Quanto maiores os montantes emprestados, maiores foram os recursos mobilizados. Apesar de não dispormos de uma variável que nos indicasse a disponibilidade desses recursos ou da produção antes dos financiamentos, as regressões efetuadas na Tabela 6 apontam para a capacidade do crédito de formar propriedades de maior tamanho e produção em escala superior. As variáveis dependentes estudadas foram a área total do proprietário, produção de café e a produtividade por mil pés de cafeeiro ${ }^{23}$. A hipoteca capturou o efeito da mobilização de recursos produtivos: o acréscimo de $1 \%$ do valor da hipoteca associou-se a um aumento de $0,655 \%$ na área possuída e de 0,708\% na produção de café. Essa forte associação sugere a existência do efeito patrimonial discutido na seção teórica, um ponto a ser explorado mais cuidadosamente na última seção. Ser italiano ou português gerou, quando significativo, um efeito negativo em termos do tamanho da propriedade e mesmo da produção, mas explicam pouco a variável dependente. Por fim, o prazo médio e a taxa de juros média anual dos empréstimos explicaram, separadamente, a área e produção. ${ }^{24} \mathrm{O}$ prazo condicionou positivamente a área e os juros negativamente a produção e a produtividade do cafeeiro. Assim, além do valor do financiamento, as condições mais favoráveis dos empréstimos também contribuíram para a formação de um patrimônio e uma maior capacidade produtiva.

Quando analisamos a relação dos empréstimos hipotecários com a produtividade, a magnitude de associação foi menor. De acordo com a regressão (5) apresentada na Tabela 6 , uma variação de $1 \%$ do valor da hipoteca foi acompanhada de uma mudança de somente $0,075 \%$ na produtividade medida-produção por mil pés de café25. A presença feminina apresentou um efeito positivo na produtividade, talvez em função do elevado porte das que realizaram hipoteca. Apenas ser italiano foi significativo na explicação da produtividade, a relação mostrou-se negativa, pois as pequenas propriedades eram menos produtivas ${ }^{26}$. Assim, os ganhos de produtividade com os empréstimos hipotecários revelaram-se muito menores do que os de dimensão da propriedade ou produção de café. 
Tabela 6 - Determinantes da área, produção e produtividade do café

\begin{tabular}{|c|c|c|c|c|c|c|}
\hline \multirow{2}{*}{$\begin{array}{l}\text { V. dependente } \\
\text { V. independentes }\end{array}$} & \multicolumn{2}{|c|}{ Área } & \multicolumn{2}{|c|}{ Produção de café } & \multicolumn{2}{|c|}{ Produtividade do cafeeiro' } \\
\hline & (1) & (2) & (3) & (4) & (5) & (6) \\
\hline \multirow[t]{2}{*}{ Constante } & $-7,286^{* * *}$ & $-7,956^{* * *}$ & $-4,404^{* * *}$ & $-4,032^{* * *}$ & $2,217^{* * *}$ & $2,886^{* * *}$ \\
\hline & $(0,000)$ & $(0,000)$ & $(0,000)$ & $(0,001)$ & $(0,000)$ & $(0,000)$ \\
\hline \multirow[t]{2}{*}{ Valor hipoteca } & $0,655^{* * *}$ & $0,674^{* * *}$ & $0,708^{* * *}$ & $0,718^{* * *}$ & $0,075^{* * *}$ & $0,069^{* * *}$ \\
\hline & $(0,000)$ & $(0,000)$ & $(0,000)$ & $(0,000)$ & $(0,000)$ & $(0,000)$ \\
\hline \multirow[t]{2}{*}{ Prazo médio } & & $0,007^{* *}$ & & & & \\
\hline & & $(0,040)$ & & & & \\
\hline \multirow[t]{2}{*}{ Juro médio } & & & & $-0,046^{* *}$ & & $-0,01$ \\
\hline & & & & $(0,014)$ & & $(0,109)$ \\
\hline \multirow[t]{2}{*}{ Italiano $^{+}$} & $-0,643^{* *}$ & & $-0,7317^{* *}$ & & $-0,208^{* *}$ & \\
\hline & $(0,043)$ & & $(0,025)$ & & $(0,000)$ & \\
\hline \multirow[t]{2}{*}{ Português ${ }^{+}$} & $-0,828^{* *}$ & $-0,732^{*}$ & $-0,823^{* *}$ & $-0,722^{*}$ & & $-0,143$ \\
\hline & $(0,046)$ & $(0,086)$ & $(0,049)$ & $(0,091)$ & & $(0,300)$ \\
\hline \multirow[t]{2}{*}{ Mulher ${ }^{+}$} & & & & & $0,307^{* *}$ & $0,695^{* * *}$ \\
\hline & & & & & $(0,047)$ & $(0,002)$ \\
\hline No observações & 145 & 135 & 132 & 116 & 132 & 116 \\
\hline $\mathrm{R}^{2}$ ajustado & 0,587 & 0,61 & 0,634 & 0,651 & 0,214 & 0,231 \\
\hline \multirow[t]{2}{*}{ Teste F } & 62,26 & 70,931 & 76,75 & 72,548 & 12,86 & 9,624 \\
\hline & $(0,000)$ & $(0,000)$ & $(0,000)$ & $(0,000)$ & $(0,000)$ & $(0,000)$ \\
\hline
\end{tabular}

Fonte: Primeiro Cartório do Registro de Imóveis e Estatística Agrícola e Zootécnica de 1904-1905.

Notas: Significância entre parêntesis: ${ }^{* * *} p<0,01,{ }^{* *} p<0,05 \mathrm{e}^{*} \mathrm{p}<0,1$; Alqueires, produção de café, valor da hipoteca e produtividade do cafeeiro estão em logaritmo; Prazo médio em meses; Juros médios anuais em porcentagem; ' ${ }^{\mathrm{v}}$ ariável dummy, ${ }^{+\dagger}$ produção de café por mil pés de cafeeiro.

\section{Efeitos Patrimonial e Garantia}

Conforme descrito na primeira seção, a Teoria Econômica baseada na literatura de Assimetria de Informação no mercado de crédito prevê uma associação positiva entre o valor das propriedades do tomador de empréstimo e o valor das hipotecas por ele contratado. Além disso, a perspectiva teórica apresentada naquela seção prevê que tal associação entre o patrimônio do empreendedor e o volume de crédito contratado via hipotecas (i) é menor entre os empreendedores com mais patrimônio e (ii) resulta de dois efeitos, denominados neste estudo como efeito garantia e efeito patrimonial.

O estudo já apresentado sobre o perfil dos agricultores que contrataram hipoteca no período 1895-1905 sugere forte associação positiva entre o patrimônio do agricultor e o valor de hipotecas. A estratégia empírica proposta na seção teórica para mensurar os efeitos patrimonial e garantia presentes nesta relação é composta de dois exercícios: (i) estudar a correlação do patrimônio de 1904-1905 com as hipotecas contratadas nos 10 anos anteriores e; (ii) estudar a correlação do patrimônio de 1904-1905 com 
as hipotecas contratadas nos 10 anos posteriores. A diferença entre a correlação do exercício (i) e a correlação do exercício (ii) é a medida proposta para o efeito patrimonial, enquanto o efeito garantia é mensurado pela correlação positiva do exercício (ii).

A fim de explorar nos dados também a previsão de menor correlação para os agricultores com mais patrimônio, a análise empírica a seguir permite uma relação não linear entre o valor contratado de hipotecas e o patrimônio dos agricultores. Concretamente, as previsões teóricas discutidas acima podem ser modeladas segundo a relação quadrática a seguir entre o valor das hipotecas (denotado por hip) e o valor estimado do patrimônio rural do agricultor (denotado por vp):

$$
\text { hip }=a+\beta_{1} v p+\beta_{2} v p^{2}+\varepsilon,
$$

em que a variável $\varepsilon$ corresponde aos fatores de hip não relacionados com $v p$ de forma quadrática e que possuem média zero.

O parâmetro a em (1) representa o valor médio da hipoteca realizada por um agricultor com patrimônio $v p=0$. A previsão de correlação positiva entre hip é $v p$ se manifestaria em (1) quando $\beta_{1}>0$. A previsão de correlação entre hip é vp menor para valores mais elevados de $v p$ estaria presente quando $\beta_{2}<0$. A Tabela 7 a seguir apresenta os resultados obtidos na estimação da relação (1).

Tabela 7 - Determinantes dos valores hipotecados e das propriedades

\begin{tabular}{|c|c|c|c|c|}
\hline \multirow{3}{*}{ V. independentes } & \multicolumn{4}{|c|}{ Variável dependente } \\
\hline & \multicolumn{2}{|c|}{ hip em 1895-1905 } & \multicolumn{2}{|c|}{ hip em 1905-1914 } \\
\hline & (1) & (2) & (3) & (4) \\
\hline \multirow[t]{2}{*}{ Constante } & $-305,907$ & & $-60,283$ & \\
\hline & $(0,156)$ & & $(0,531)$ & \\
\hline \multirow[t]{2}{*}{$v p$} & $3,033^{* * *}$ & $2,625^{* * *}$ & $1,520^{* * *}$ & $1,408^{* * *}$ \\
\hline & $(0,000)$ & $(0,000)$ & $(0,000)$ & $(0,000)$ \\
\hline \multirow[t]{2}{*}{$v p^{2} \cdot\left(10^{-10}\right)$} & $-3,626^{* * *}$ & $-3,018^{* * *}$ & $-3,469^{* * *}$ & $-3,210^{* * *}$ \\
\hline & $(0,001)$ & $(0,002)$ & $(0,000)$ & $(0,000)$ \\
\hline \multirow[t]{2}{*}{ Alemão ${ }^{+}$} & $62.324^{* * *}$ & $51.574^{* *}$ & $77.318^{* * *}$ & $71.794^{* * *}$ \\
\hline & $(0,005)$ & $(0,013)$ & $(0,001)$ & $(0,000)$ \\
\hline \multirow[t]{2}{*}{ Mulher $^{+}$} & 1.134 & 959 & $1.720^{* * *}$ & $1.713^{* * *}$ \\
\hline & $(0,203)$ & $(0,278)$ & $(0,001)$ & $(0,001)$ \\
\hline $\mathrm{N}^{\circ}$ observações & 144 & 144 & 79 & 79 \\
\hline $\mathrm{R}^{2}$ ajustado & 0,300 & 0,321 & 0,500 & 0,560 \\
\hline \multirow[t]{2}{*}{ Teste F } & 16,347 & 18,049 & 20,506 & 26,148 \\
\hline & $(0,000)$ & $(0,000)$ & $(0,000)$ & $(0,000)$ \\
\hline
\end{tabular}

Fonte: Primeiro Cartório do Registro de Imóveis e Estatística Agrícola e Zootécnica de 1904-1905.

Notas: Significância entre parêntesis: ${ }^{* * *} p<0,01,{ }^{* *} p<0,05$ e ${ }^{*} p<0,1 ;$ hip: valor das hipotecas (em contos de Réis). vp: valor das propriedades (em contos de Réis). 'variável dummy. 
As regressões (1) e (2) correspondem ao exercício (i) sugerido na seção teórica e se distinguem pela inclusão ou não da constante dentre as variáveis independentes. As regressões (3) e (4) correspondem ao exercício (ii) sugerido na seção teórica e, novamente, se distinguem pela inclusão ou não da constante dentre as variáveis independentes. A notação $v p^{2} \times 10^{-10}$ indica que o coeficiente estimado para a variável $v p^{2}$ é apresentado na Tabela 7 multiplicado por $10^{-10}$. Por exemplo, o valor $-3,626$ apresentado na regressão (1) para a variável $v p^{2}$ indica que $\hat{\beta}_{2}=-3,626 \times 10^{-10}$.

Além das variáveis sugeridas pela equação (1), são consideradas nas regressões (1) a (4) duas variáveis binárias/dummies: uma para Alemão e outra para Mulher. Dessa forma, o valor estimado para o coeficiente da constante, $\hat{a} \approx-305$, deve ser interpretado como o valor médio de crédito contratado via hipoteca por agricultores homens não alemães e sem patrimônio imóvel. Sinal negativo para este coeficiente deve ser interpretado como indicativo de que agricultores deste grupo e com patrimônio imóvel próximo de zero não contrataram hipoteca. A baixa significância estatística de â, no entanto, não permite afirmar $a<0$. O valor positivo para os coeficientes das variáveis Alemão e Mulher indicam que o valor médio das hipotecas contratadas por alemães e por mulheres sem patrimônio $(v p=0)$ é maior do que o valor médio contratado por homens não alemães sem patrimônio.

O valor positivo e estatisticamente significante (diferente de zero) estimado para $\beta_{1}$ identifica mais uma vez o padrão de associação positiva entre hip e vp obtido na terceira seção. $O$ valor estatisticamente significante estimado para $\beta_{2}$ confirma que o padrão de associação entre hip e vp é não linear. Em conjunto, os valores estimados $\hat{\beta}_{1}>0$ e $\hat{\beta}_{2}<0$ indicam que o grau de associação entre hip e vp é positivo e se enfraquece (diminui) com o aumento do patrimônio do agricultor $(v p)$, conforme previsto pela Teoria apresentada na seção teórica.

O valor estimado para $\beta_{1}$ nas regressões (1) e (2) mede o grau de associação entre o valor total de hipotecas contratado no período 1895-1905 com o patrimônio em 1904-1905 do tomador do crédito. Por exemplo, a regressão (1) mostra que um aumento de 1 conto de réis no patrimônio do agricultor é acompanhado de um aumento de aproximadamente 3 contos de réis no valor de crédito contratado via hipoteca. Conforme discutido anteriormente, nesta medida estão inclusos os efeitos garantia e patrimonial. Para mensurar tais efeitos em separado, utiliza-se o coeficiente $\beta_{1}$ estimado nas regressões (3) e (4).

O valor estimado para $\beta_{1}$ nas regressões (3) e (4) mede o grau de associação entre o valor total de hipotecas contratado no período 1905-1914 com o patrimônio em 1904-1905 do tomador do crédito. A regressão (3), por exemplo, mostra que um aumento de 1 conto de réis no patrimônio do agricultor é acompanhado de um aumento de aproximadamente 1,5 contos de réis no valor de crédito contratado via hipoteca. Como nestas regressões o dado de patrimônio é anterior ao registro de hipoteca, é difícil imaginar que tal medida de associação inclua o efeito patrimonial. Trata-se da medida do efeito garantia: cada aumento de 1 conto de réis no patrimônio imóvel do agricultor permitiu a este agricultor elevar seu montante de crédito via hipoteca em 1,5 contos de réis. 
Seguindo o argumento exposto acima, a diferença entre os valores estimados para $\beta_{1}$ nas regressões (3) e (1) se deve ao efeito patrimonial. Similarmente, uma estimativa para o efeito patrimonial pode ser obtida subtraindo do valor estimado para $\beta_{1}$ na regressão (2) o valor estimado para $\beta_{1}$ na regressão (4). Se $\hat{\beta}_{1}^{(i)}$ denota o valor estimado para $\beta_{1}$ na regressão (i), então a estimativa para o efeito patrimonial proporcionada pelas regressões (1) e (3) é dado por $\hat{\beta}_{1}^{(1)}-\hat{\beta}_{1}^{(3)}=1,513$ : cada aumento em 1 conto de réis no montante de crédito contratado pelo agricultor provoca um aumento de 1,513 contos de réis em seu patrimônio ${ }^{27}$.

Em suma, a análise empírica realizada revelou que os dois efeitos ocorriam em Ribeirão Preto no período estudado.

\section{Considerações finais}

A comarca de Ribeirão Preto constituía um grande centro produtor cafeeiro no início do século XX. A grande colheita de café nesse momento ocorreu em conjunto com grandes negociações hipotecárias entre 1895 e 1905. Esse crédito via hipoteca abarcou uma parcela expressiva dos agricultores no censo de 1904-1905. Muito mais do que um número significativo de produtores que realizaram hipoteca, as relações de crédito alcançaram grande parcela dos recursos produtivos, como área, valor dos estabelecimentos, trabalhadores, pés e produção de café. As unidades produtivas que contaram com o apoio hipotecário eram principalmente as de maior porte, abarcando muito mais recursos do que as demais. A produtividade das que se utilizaram da hipoteca também superou as que não empregavam. A presença do crédito hipotecário entre os maiores proprietários de terras revelou-se muito mais frequente do que a entre os possuidores de propriedades menores. Desconsiderando os dois estrangeiros de porte muito diferenciado, os nascidos no exterior detinham propriedades em média menores do que os brasileiros, como os recém-chegados italianos e austro-húngaros, mas até mesmo os portugueses que já estavam a mais tempo no país.

A análise empírica mostra que a associação entre patrimônio mais elevado e valores de crédito hipotecário maiores decorre de dois efeitos: o efeito da hipoteca em aumentar o patrimônio do agricultor (denominado efeito patrimonial) e o efeito do patrimônio do agricultor na capacidade de contratação de hipoteca (denominado efeito garantia). A identificação da presença simultânea e relevante destes dois efeitos é bastante importante, pois evidencia que a alocação de crédito hipotecário se concentrou nos maiores proprietários (consequência do efeito garantia) e que o patrimônio dos agricultores que hipotecaram seus imóveis gozou de maior rentabilidade (consequência do efeito patrimonial). Em conjunto, a distribuição de crédito concentrada entre os maiores agricultores e a existência do efeito patrimonial podem ser vistas como promotoras de desigualdade de patrimônio entre os agricultores. A desigualdade do crédito acentuou as diferenças de recursos que já existiam anteriormente, contribuindo para a elevação das distinções entre os produtores agrícolas. Assim, a hipoteca na agricultura agravou a desigual distribuição de recursos produtivos e das próprias colheitas. 


\section{Referências}

AKERLOF, G. A. The market for "lemons": Quality uncertainty and the market mechanism. In: DIAMOND, P.; ROTHSCHILD, M. Uncertainty in economics. Elsevier, 1978, p. 235-251.

BACELLAR , C. D. A. P.; BRIOSCHI , L. R. Na Estrada do Anhangüera: uma visão regional da história paulista. São Paulo: Humanitas Publicacoes; FFLCH/USP, 1999.

BASSANEZI, M.; FRANCISCO, P. Estado de São Paulo. estatística agrícola e zootécnica, 1904-1905. Campinas: Nepo/Unicamp, 2003.

SAES, F. A. M. Crédito e bancos no desenvolvimento da economia paulista, 1850-1930. São Paulo: Instituto de Pesquisas Econômicas, 1986.

DIAMOND, D. W. Financial intermediation and delegated monitoring. The Review of Economic Studies, v. 51, n. 3, p. 393-414, 1984.

DIAMOND, D. W. Monitoring and reputation: The choice between bank loans and directly placed debt. Journal of political Economy, v. 99, n. 4, p. 689-721, 1991

DIAMOND, D. W. Financial intermediation as delegated monitoring: A simple example. Richmond Economic Quarterly, v. 82, n. 3, 51-66, 1996.

FALEIROS, R. N. Major claudiano \& família: o empobrecimento e o descrédito como elementos para a compreensão dos negócios no complexo cafeeiro (1893-1909). Locus - Revista de História, v. 20, n. 2, p. 77-96, 2014.

FONTANARI, R. O problema do financiamento: uma análise histórica sobre o crédito no complexo cafeeiro paulista. Casa Branca (1874-1914). Dissertação (Mestrado) Faculdade de Ciências Humanas e Sociais da Universidade Estadual Paulista, 2011.

FONTANARI, R. Um banqueiro do café: a trajetória empresarial do Coronel Christiano Osório de Oliveira e as teias do crédito na economia cafeeira paulista (1890-1937). Tese (Doutorado) - Faculdade de Filosofia, Letras e Ciências Humanas. Universidade de São Paulo, 2015.

GOLDSMITH, R. W. Brasil 1850-1984: desenvolvimento financeiro sob um século de inflação. São Paulo: Harper \& Row, 1986.

HANLEY, A. G. Native capital: financial institutions and economic development in São Paulo, Brazil, 1850-1920. Stanford: Stanford University Press, 2005.

HERTZBERG, A., LIBERMAN, A.; PARAVISINI, D. Screening on loan terms: evidence from maturity choice in consumer credit. The Review of Financial Studies, v. 31, n. 9, p. 3532-3567, 2018.

LOPES, L. S. Sob os olhos de São Sebastião: a cafeicultura e as mutações da riqueza em ribeirão preto, 1849-1900. Tese (Doutorado). Faculdade de Filosofia, Letras e Ciências Humanas. Universidade de São Paulo, 2005. 
LUNA, F. V.; KLEIN , H. S.; SUMMERHILL, W. R. A agricultura paulista em 1905. Estudos Econômicos (São Paulo), v. 44, n. 1, p. 153-184, 2014.

MAS-COLELL, A.; WHINSTON, M. D.; GREEN, J. R. Microeconomic Theory. New York: Oxford University Pres, 1995, v. 1.

MISHKIN, F. S. The economics of money, banking, and financial markets. New York: Pearson, 2007.

MORAES, M. L. D. P. M. Atuação da firma Theodor Wille \& Cia. no mercado cafeeiro do Brasil, 1844-1918. São Paulo: FFLCH (1988).

PIÑEIRO, T. L. A carteira hipotecária do Banco do Brasil: os conflitos em torno do crédito agrícola no II Reinado. Campos em disputa: história agrária e companhia. São Paulo: Annablume (2007), 41-62.

PINO, Francisco Alberto. Centenário do censo agronômico. Informações Econômicas (São Paulo), v. 35, n. 5, p. 85-87, 2005.

PIRES, A. Café, finanças e indústria: Juiz de Fora, 1889-1930. Juiz de Fora: FUNALFA, Prefeitura de Juiz de Fora, 2009.

RIBEIRO, M. A. R. Riqueza e endividamento na economia de plantation açucareira e cafeeira: a família Teixeira Vilela-Teixeira Nogueira, Campinas, São Paulo, século XIX. Estudos Econômicos (São Paulo), v. 45, p. 3, p. 527-565, 2015.

SAES, Flávio Azevedo Marques de. Crédito e bancos no desenvolvimento da economia paulista (1850-1930). São Paulo: IPE/USP, 1986.

SWEIGART, J. E. Financing and Marketing Brazilian Export Agriculture: The coffee Factors of Rio de Janeiro, 1850-1888. Tese (Phd em História). University of Texas, 1980.

TEODORO, R. D. S. O crédito no mundo dos senhores do café: Franca 1885-1914. Dissertação (Mestrado em História Econômica). Universidade Estadual de Campinhas, 2006.

TOSI, Pedro Geraldo; FALEIROS, Rogério Naques; FONTANARI, Rodrigo. Modalidades e hierarquias do crédito na cafeicultura paulista (1889-1930). Revista Brasileira de Economia, v. 65, n. 4, p. 401-412, 2011.

TRINER, G. Banking and economic development: Brazil, 1889-1930. New York: Palgrave, 2000.

VARIAN, H. R. Microeconomia: princípios básicos. São Paulo: Elsevier Brasil, 2006. 


\section{NOTAS}

1Decreto 482 de 14 de novembro de 1846, Lei 1.237 de 24 de setembro de 1864, Decreto 3.453 de 26 de abril de 1865, Decreto 2.687 de 6 de novembro de 1875, Decreto 3.272 de 5 de outubro de 1885 e Decreto 169A 19 de janeiro de 1890.

2 Bacellar (1999) e Lopes (2005). A região da Mogiana respondeu por um terço da produção de café no censo de 1904-1905 (Cf. LUNA; KLEIN; SUMMERHILL, 2014, p. 158). Utilizamos a comarca de Ribeirão Preto no início do século XX, que ainda compreendia Sertãozinho e Cravinhos, embora já fossem emancipados.

3 Os livros de inscrição hipotecária encontram-se depositados no $1^{\circ}$ Cartório de Registro de Imóveis de Ribeirão Preto. A Estatística Agrícola e Zootécnica de 1904-1905 foi consultada por meio da publicação de Bassanezi e Francisco (2003).

${ }^{4}$ No Apêndice B é apresentada uma descrição mais detalhada e precisa da perspectiva teórica discutida nesta seção.

${ }_{5}^{5}$ Pelo menos por meio deste canal. A restrição de crédito não alteraria os montantes financiados para os que possuem patrimônio elevado. Alternativamente, outras formas de levantar recursos podem ser utilizadas, como autofinanciamento. A eventual atratividade do autofinanciamento poderia diminuir o montante de crédito contratado via hipoteca.

6 Note que correlação intertemporal positiva para o patrimônio não indicaria que patrimônio cresce ao longo do tempo. Ela indicaria que empreendedores com mais patrimônio em períodos anteriores tendem a possui mais patrimônio no período atual. É possível verificar tal padrão com patrimônio decrescente, desde que a taxa de decrescimento tenda a ser semelhante entre empreendedores. Agradecemos a um dos avaliadores por apontar a necessidade de esclarecimento sobre este ponto.

7 O Decreto estadual 1.323 de 23 de outubro de 1905 aprovou as instruções para o levantamento da estatística agrícola e zootécnica. A legislação determinou a contratação remunerada de delegados para cada zona e de um auxiliar para os municípios e também os formulários de coleta das informações. Para o preenchimento deles, os auxiliares deveriam se "dirigir se pessoalmente a cada propriedade ou a quem suas vezes possa fazer”, na recusa procurará as informações com vizinhos. Ver Pino (2005).

8 Como a grande maioria das terras era roxa, os valores do solo por alqueire variavam entre 80.000 e 400.000 réis para a maior parte dos estabelecimentos. O valor total dos estabelecimentos variou mais mesmo quando calculamos por alqueire, encontrando-se na faixa de 200.000 a 2.000.000. Isto apontou que benfeitorias, plantações e animais detinham grande importância para a avaliação das propriedades.

9 Como no censo agrícola somente havia o nome da pessoa, sem o do cônjuge, e o registro hipotecário é manuscrito com a grafia da época, o cruzamento dos nomes das pessoas nas duas fontes mostrou-se algumas vezes duvidoso. Tentamos juntar casos de variações em um dos nomes.

10 Ribeirão Preto constituiu vila em 1871, que foi instalada em 1874.

${ }^{11} \mathrm{~A}$ fonte é a Ata número 10, depositada no Arquivo Municipal de Ribeirão Preto.

$12 \mathrm{O}$ plantio ocorria provavelmente entre as fileiras dos cafezais, principalmente dos mais novos. Isto não ocorria com o cultivo da cana. 
13 Havia mais de cinco mil animais cavalares, onze mil vacuns, quase quatro mil muares e doze mil de caprinos. Os suínos e as aves domésticas constituíam os mais numerosos, com 47 mil os primeiros e quase 140 mil as segundas.

14 O Banco de Ribeirão Preto mantinha, em dezembro de 1901, 488 contos de réis em hipotecas e 1.276 contos em letras, obrigações e títulos a receber; e, em junho de 1902, 250 contos em hipotecas e 1.128 em letras e títulos a receber, representando as primeiras 38,2\% e 22,2\% das segundas, respectivamente (cf. Estado de São Paulo, 30 de janeiro de 1902, p. 4; e de 26 de julho de 1902, p. 5). Essa instituição bancária de pequeno porte consistia num banco comercial não especializado no crédito hipotecário.

15 Veridiana Valéria da Silva Prado e filhos detinham quase 14 mil alqueires de terra no censo e Martinho da Silva Prado Júnior pouco mais de seis mil alqueires. A primeira detinha a maior extensão de terras da comarca de Ribeirão Preto.

16 No jornal O Comércio de São Paulo, de 19 de fevereiro de 1905, havia um anúncio de uma fazenda de café com 100 alqueires e 60 mil pés de café, oferecida por 45 contos de réis (p. 3).

17 Os bancos realizaram entre 1895 e 1905 trinta hipotecas rurais na condição de credores, somando 9.211 contos de réis. O prazo médio foi de 50 meses e a taxa de juros média anual de 9,9\% ao ano. Desse modo, eles emprestavam quantias acima da média das transações a prazos maiores e juros menores. Os demais credores consistiram em pessoas físicas e jurídicas, como casas exportadoras, sendo a principal a Theodor Wille que emprestava a Schmidt.

18 Nos casos que houve a sucessão da propriedade, como por conta de falecimento do anterior proprietário, tentamos verificar o nome do sucessor quando conhecido. Infelizmente podemos ter perdido alguns casos em razão dessa ocorrência e da alteração do proprietário entre a data da hipoteca e o censo, como a venda do imóvel. O registro da hipoteca informa os nomes dos proprietários, se um casal tanto do homem quanto da mulher. O censo informa apenas os nomes dos proprietários, porém sem menção aos cônjuges. Assim, para verificar se não havia o problema de homônimo lançamos mão da descrição do imóvel nas duas fontes, como área, cafezal etc.

19 A correlação entre valor da hipoteca e área da propriedade foi de 0,831 e com relação ao número de trabalhadores foi de 0,775 . A produção de café apresentou uma correlação com as quantias hipotecadas de 0,799.

20 No Apêndice, realizamos regressões com variáveis correlacionadas como dependentes: trabalhadores, valor das propriedades e produtividade por trabalhador. Os resultados foram semelhantes aos apresentados na Tabela 6.

${ }^{21}$ Não utilizamos as variáveis juros e prazo simultaneamente nas regressões, em virtude das duas serem correlacionadas. A correlação de prazo e juros médios foi de -0,283.

22 No Apêndice, verificamos que a variação de $1 \%$ do valor hipotecário foi acompanhada de uma mudança de 0,099\% na produção por trabalhador. Tal evidência sugere que o impacto da hipoteca nos indicadores relacionados à produção é maior do que naqueles de produtividade.

${ }^{23} \mathrm{~A}$ correlação entre produtividade e área para os que fizeram hipoteca foi de 0,338, bastante inferior as correlações apresentadas acima entre a produção e os fatores de produção.

${ }^{24} \mathrm{~A}$ diferença entre as estimativas obtidas nestas regressões é estatisticamente significante (diferente de zero). Em grandes linhas, a significância estatística do efeito patrimonial pode ser estudada utilizando o desvio padrão do estimador $\hat{\beta}_{1}$ de cada regressão. Por exemplo, o desvio padrão de $\hat{\beta}_{1}$ é igual a $\hat{\sigma}_{1}^{(1)}=0,552$ na regressão (1) e igual a $\hat{\sigma}_{1}^{(3)}=0,303$ na regressão (3). Uma 
medida de desvio padrão do efeito patrimonial $\left(\hat{\beta}_{1}{ }^{(1)}-\hat{\beta}_{1}{ }^{(3)}\right)$ é dada por $\sqrt{\left[\hat{\sigma}_{1}^{(1)}\right]^{2}+\left[\hat{\sigma}_{1}^{(1)}\right]^{2}}=0,630$. Assim, a razão entre $\left(\hat{\beta}_{1}^{(1)}-\hat{\beta}_{1}{ }^{(3)}\right)$ e $\sqrt{\left[\hat{\sigma}_{1}^{(1)}\right]^{2}+\left[\hat{\sigma}_{1}^{(3)}\right]^{2}}$ é dada por 2,403. Como a probabilidade de uma variável aleatória com distribuição Normal padronizada assumir valores acima de 2,4 é de aproximadamente $0,82 \%$, se a distribuição de tal razão é aproximadamente Normal, é pouco provável que ela tenha média zero.

\section{Nota do Editor}

A revista História (São Paulo) agradece à FAPESP pelo apoio financeiro, na modalidade Auxílio à Pesquisa - Publicações/Periódicos (Processo n. 2020/04324-9), para a publicação deste artigo.

\section{AGRADECIMENTOS}

Os autores agradecem aos bolsistas Paulo Rogério Maduro Júnior, Lucas Sola Losa, Marcos Andrade Alves, Ulysses de Paiva Faleiros Neto, Victor Augusto de Almeida Oliveira e Caio Vinicius da Silva Albanezi, da Universidade de São Paulo, pelo apoio na coleta e processamento das informações para a pesquisa.

\section{DECLARAÇÃO DE FINANCIAMENTO}

Este trabalho contou com o apoio da FAPESP, processo 2007/00429-6, e do CNPq, ao primeiro autor.

Renato Leite MARCONDES. Economista e Doutor em Economia pela Universidade de São Paulo. Professor Associado da Faculdade de Economia, Administração e Contabilidade de Ribeirão Preto da Universidade de São Paulo (FEARP/USP). Pesquisa na área de história econômica e demográfica, principalmente os temas: crédito, hipoteca, acumulação de riqueza, cafeicultura, posse de escravos, desigualdade regional e comércio.

Jefferson BERTOLAI. Professor e Pesquisador da Faculdade de Economia, Administração e Contabilidade de Ribeirão Preto da Universidade de São Paulo (FEARP/USP). Possui graduação em Economia pela Universidade de São Paulo (2006), mestrado em Economia pela Fundação Getúlio Vargas (2009) e doutorado em Economia pela Fundação Getúlio Vargas (2012). Tem experiência na área de Economia, com ênfase em Teoria Monetária e Bancária, atuando principalmente nos seguintes temas: instabilidade bancária, distribuição de liquidez e criptomoedas \& blockchain. Desde 2018 é coordenador do Laboratório de Economia, Matemática e Computação (LEMCFEARP/USP). 


\section{Apêndice A}

Tabela A.1 - Determinantes do trabalho, valor das propriedades e produtividade do café.

\begin{tabular}{|c|c|c|c|c|c|c|}
\hline \multirow{2}{*}{$\begin{array}{l}\text { Variáveis } \\
\text { Independentes }\end{array}$} & \multicolumn{2}{|c|}{ Trabalhadores } & \multicolumn{2}{|c|}{ Valor } & \multicolumn{2}{|c|}{ Produtividade } \\
\hline & (1) & (2) & (3) & (4) & (5) & (6) \\
\hline \multirow[t]{2}{*}{ Valor da hipoteca } & $0,6367^{* * *}$ & $0,5957^{* * *}$ & $0,7449^{* * *}$ & $0,7023^{* * *}$ & $0,1012^{* * *}$ & $0,0985^{*+*}$ \\
\hline & $(0,000)$ & $(0,000)$ & $(0,000)$ & $(0,000)$ & $(0,000)$ & $(0,000)$ \\
\hline \multirow[t]{2}{*}{ Italiano } & & $-0,5492^{* *}$ & & $-0,5907^{*}$ & & \\
\hline & & $(0,049)$ & & $(0,079)$ & & \\
\hline \multirow[t]{2}{*}{ Português } & & $-0,7015^{* *}$ & & $-0,6640$ & & \\
\hline & & $(0,055)$ & & $(0,130)$ & & \\
\hline \multirow[t]{2}{*}{ Mulher } & & & & & & 0,3466 \\
\hline & & & & & & $(0,115)$ \\
\hline \multirow[t]{2}{*}{ Constante } & $-7,804^{* * *}$ & $-6,945^{* * *}$ & $4,733^{* * *}$ & $5,622^{* * *}$ & $2,677^{* * *}$ & $2,709^{* * *}$ \\
\hline & $(0,000)$ & $(0,000)$ & $(0,000)$ & $(0,000)$ & $(0,000)$ & $(0,000)$ \\
\hline Nº Observações & 144 & 144 & 144 & 144 & 132 & 132 \\
\hline $\mathrm{R}^{2}$ ajustado & 0,5868 & 0,5998 & 0,5762 & 0,5841 & 0,1230 & 0,1331 \\
\hline Teste F & 204,10 & 72,45 & 195,41 & 67,95 & 19,38 & 11,06 \\
\hline Prob $>$ F & 0,000 & 0,000 & 0,000 & 0,000 & 0,000 & 0,000 \\
\hline
\end{tabular}

Notas: Significância entre parêntesis: ${ }^{* * *} p<0,01,{ }^{* *} p<0,05 e^{*} p<0,1$; Produção, valor da hipoteca e produtividade estão em logaritmo; Produtividade é produção de café por trabalhador. Italiano, português e mulher são variáveis dummy.

Fonte: Primeiro Cartório do Registro de Imóveis e Estatística Agrícola e Zootécnica de 1904-1905. 
Figura A1 - Zona Cafeeira do Estado de São Paulo (1907).

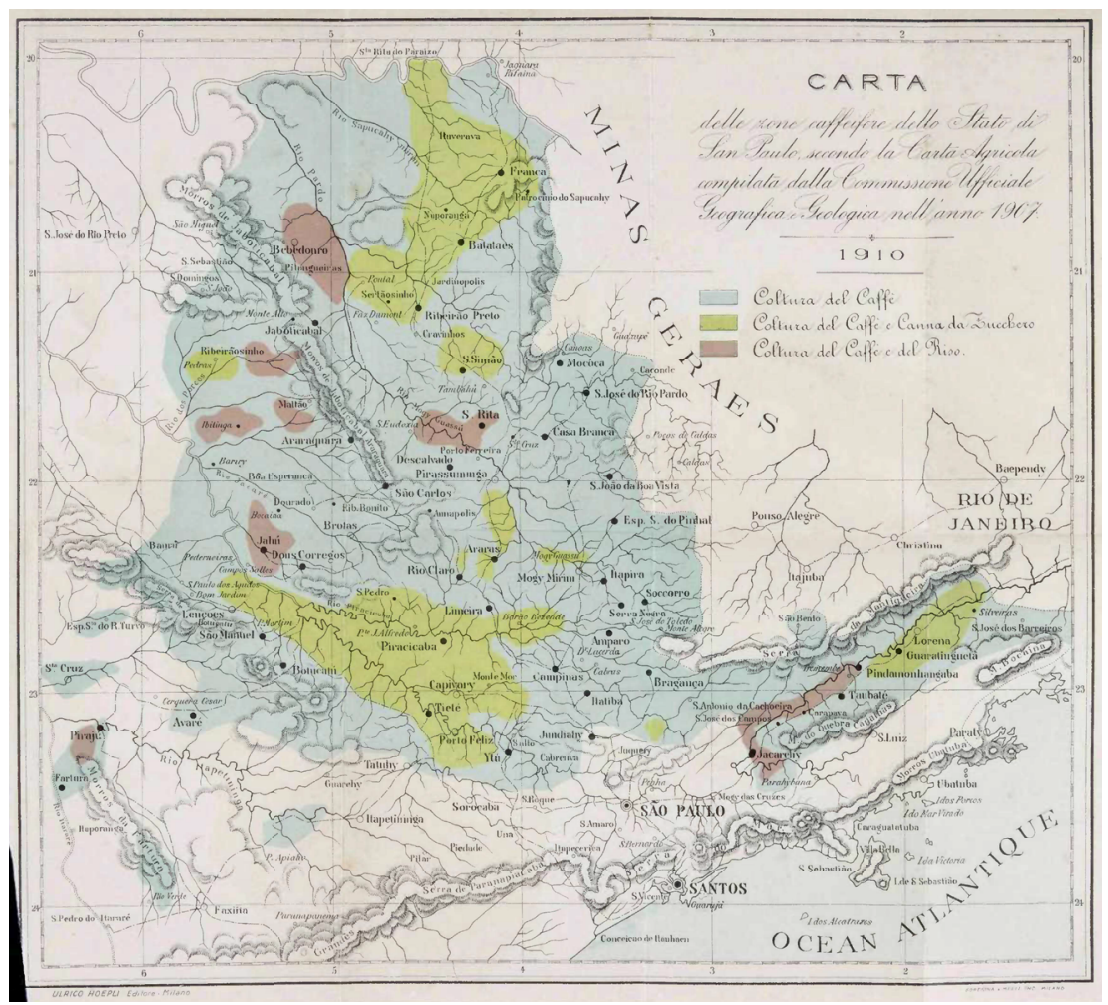

Fonte: BELLI, B. I/ Caffè il suo paese e la sua importanza (S. Paulo del Brasile). Milano: Ulrico Hoepli, 1910 Disponível em: <https://digital.bbm.usp.br/handle/bbm/3864> 


\section{Apêndice B}

\section{Perspectiva Teórica}

\section{B.1 - Crédito com colateral}

O descasamento entre projetos de investimento e disponibilidade de poupança é uma importante característica da organização econômica. Frequentemente, os agentes com poupança positiva (poupadores) não possuem acesso para execução às oportunidades de investimento mais atrativas. Tal descasamento faz com que a canalização de recursos dos poupadores para os agentes com acesso aos projetos de investimento seja uma atividade socialmente atrativa.

O mercado (compradores e vendedores interagindo por meio de um sistema de preços) é a instituição mais frequentemente considerada pela Teoria Econômica para viabilizar trocas voluntárias entre indivíduos. Se utilizado para a canalização de recursos, um mercado de poupança estabeleceria um preço (taxa de juros) pago ao poupador para convencê-lo a abrir mão de seus recursos durante o período de maturação do projeto de investimento financiado. Se o poupador acreditar/confiar que seu recurso será devolvido no futuro, acrescido do preço (taxa de juros) prometido, ele abre mão de consumo corrente em troca de consumo futuro.

Conforme estabelecido pelo / Teorema de Bem Estar Social da Teoria Econômica, o bom funcionamento (eficiência de Pareto) do mercado é garantido se os mercados são completos e os agentes encaram competição perfeita nos mercados em que atuam (e, portanto, são tomadores de preços)'. A completude de mercados significa a existência de um mercado para cada bem existente na economia. Por exemplo, dois mercados de carros usados precisam existir em uma economia com mercados completos se há dois (e somente dois) tipos de carros usados: carros de qualidade alta e carros de qualidade baixa. Se as duas qualidades de carro são transacionadas em um mesmo mercado (ao mesmo preço), então os mercados não são completos". Adicionalmente, a existência de mercados requer a confiança de que os termos de troca serão respeitados. Tal requerimento é especialmente crítico em mercados nos quais a relação de troca não é estática. Se a finalização da troca ocorre em período futuro (como é o caso do mercado de crédito), é necessário que a parte devedora seja capaz de se comprometer previamente com suas promessas (possua comprometimento) ou, caso não possua comprometimento, que ela seja incentivada a honrar suas promessas.

A presença de assimetria de informação na relação de crédito, no entanto, é pervasiva. O proprietário do projeto de investimento (doravante denominado empreendedor) possui mais conhecimento sobre a qualidade de sua oportunidade de investimento do que o potencial financiador (poupador). Além disso, o comportamento do empreendedor após firmado o contrato de crédito não é perfeitamente observável pelos poupadores, o que possibilita comportamentos oportunistas prejudiciais aos credores. O primeiro tipo de assimetria de informação dificulta a organização de um 
mercado para cada tipo de projeto de investimento. O típico resultado de ineficiência em casos como este é conhecido como Seleção Adversa: somente projetos de investimento de baixa qualidade são transacionados em equilíbrio. No segundo tipo de assimetria, os credores antecipam eventuais comportamentos oportunistas e, por isso, estão menos dispostos a emprestar seus recursos. Este fenômeno é conhecido como Moral Hazard e, tipicamente, provoca aumento no preço (taxa de juros) de equilíbrio. Em casos extremos de assimetria de informação (Seleção Adversa e/ou Moral Hazard), todo o mercado de crédito desaparece.

Dada a pervasividade de assimetria de informação na relação de crédito, o sistema bancário é visto como uma instituição alternativa ao mercado na intermediação de recursos entre poupadores e projetos de investimento. O problema de assimetria pré-contratual (seleção adversa) é enfrentado pelos bancos por meio de um esforço prévio de coleta de informações sobre a atratividade do projeto e por meio de um processo de triagem (usualmente denominado screening), no qual a oferta de um menu de opções de empréstimos bancários induz empreendedores com projetos mais arriscados a escolher contratos mais custosos'"'. O problema de assimetria de informação pós-contratual (moral hazard) é enfrentado por meio de um esforço de monitoramento da execução dos projetos de investimento e do estabelecimento prévio de punições ao devedor em caso de identificação de comportamentos oportunistas durante a execução do projeto.

Os típicos instrumentos de enfrentamento a assimetria de informação (a oferta de um menu de opções de empréstimos e monitoramento de projetos, acompanhado de punições ao devedor em caso de detecção de oportunismo) não são inconsistentes com a organização do sistema de crédito via mercados. Mas o custo envolvido na coleta e na produção de informações sobre cada projeto e sobre sua execução, assim como a característica de bem não rival da informação assim produzida, torna o mercado uma instituição socialmente ineficiente. Ao concentrar no sistema bancário a produção/coleta de informações, a concessão de crédito e o monitoramento dos projetos, a sociedade é capaz de explorar melhorias de Paretoıv.

Bens duráveis também podem ser (e frequentemente são) utilizados na relação de crédito como um importante instrumento para enfrentar os problemas decorrentes da existência de assimetria de informação, tanto pré-contratuais quanto pós-contratuais. Nesta modalidade de crédito, o empreendedor autoriza uma terceira parte (quase sempre, o Estado) a transferir sua propriedade sobre um dado bem durável (usualmente, um imóvel) para o credor em caso de descumprimento de cláusulas do contrato de empréstimo. Ou seja, o bem durável é usado como colateral (garantia) no contrato de empréstimo.

Se os credores acreditam na capacidade desta terceira parte em transferir a propriedade de maneira rápida e eficaz (especialmente na situação em que o empreendedor se arrepende da autorização cedida previamente) e confiam na manutenção do valor de mercado do bem durável, eles então antecipam baixo risco de inadimplência na relação de crédito devido a comportamentos oportunistas não observáveis. Antecipam que o empreendedor possuirá bastante interesse, 
após a assinatura do contrato, em cumprir suas promessas (evitar comportamentos oportunistas) como forma de não perder sua propriedade. Em outras palavras, o uso de colateral ameniza os efeitos do Moral Hazard. Além disso, quando a assimetria de informação é pré-contratual (por exemplo, reside no risco de retorno do projeto a ser financiado), os credores antecipam que empreendedores com projetos mais atrativos (exemplo, menos arriscados) estão dispostos a oferecer mais garantias/colateral do que aqueles com projetos menos atrativo (mais arriscados). Dessa forma, o nível de garantia/colateral oferecido pelo empreendedor sinaliza/revela a qualidade (o grau de risco) do seu projeto.

Ao amenizar os efeitos de Seleção Adversa e de Moral Hazard, a utilização de colateral em contratos de empréstimos ameniza as típicas ineficiências destes fenômenos: permite taxas de juros menores para projetos mais atrativos (denominado efeito na margem intensiva) e viabiliza o financiamento de projetos de atratividade maior (denominado efeito na margem extensiva).

O potencial que a utilização de colateral possui para amenizar os problemas causados pela existência de assimetria de informação na relação de crédito depende, portanto, fundamentalmente da capacidade da terceira parte em transferir a propriedade do bem durável. A utilização simultânea do bem durável como garantia/colateral em poucos contratos de empréstimo é componente central para preservar tal capacidade. A complexidade do processo de transferência de propriedade de um bem durável dado em garantia para mais de um credor é bastante grande e pode inviabilizar a utilização de colateral em relações de crédito.

Segue do exposto que é bastante importante para o credor, no momento de celebração de um dado contrato de empréstimo, saber a quantidade de vezes que o bem durável a ele prometido como colateral estará prometido para outros credores durante a vigência de seu contrato. Para esta necessidade, é ineficiente cada um dos credores coletar e manter informações sobre a utilização dos bens duráveis dos empreendedores. A centralização da coleta e manutenção de tais informações em um único agente (frequentemente um cartório) emerge como a solução natural, desde que as informações sejam compartilhadas com os credores interessados. Naturalmente, este agente garantiria publicidade tanto do registro de propriedade do bem durável quanto do registro dos contratos de empréstimo nos quais o bem foi usado como colateral.

\section{B.2 Hipotecas}

O arcabouço teórico aqui apresentado é fundamental para o entendimento e análise da relação de crédito denominada Hipoteca. Nesta modalidade de crédito, um bem imóvel é usado como garantia/colateral e a terceira parte designada para transferir a propriedade-garantia é o Estado - por meio de seu sistema judiciário. Em caso de descumprimento de cláusulas contratuais por parte do empreendedor, os credores acionam o judiciário para executar a hipoteca (transferir a propriedade do colateral/imóvel). Para este caso a publicidade das hipotecas por meio de seu registro favorece a sua utilização, uma vez que reduz o problema de assimetria de informação. 
A oferta de recursos por meio de contratos de hipoteca, portanto, depende diretamente do valor de mercado do imóvel dado em garantia e da capacidade de a terceira parte transferir a propriedade do colateral. Se o valor do imóvel é alto e o Judiciário possui facilidade/agilidade para executar a hipoteca, o montante de crédito ofertado via hipoteca do referido imóvel será alto e a taxa de juros cobrada será menor. Se o valor do imóvel é baixo e o Judiciário enfrenta dificuldades para (ou se recusa a) executar a hipoteca, o montante de crédito ofertado via hipoteca será baixo e a taxa de juros será alta. Em particular, o credor não aceitará imóveis de baixo valor como garantia em contratos de hipoteca se este antecipa um custo fixo relevante para avaliar, monitorar e executar a hipoteca.

Conforme discutido acima, o sistema de crédito resolve um importante problema de alocação de recursos: o descasamento entre disponibilidade de poupança e acesso a projetos de investimentos. Ao melhorar a canalização de poupança para bons projetos de investimento, o crédito melhora tanto a situação dos poupadores quanto a situação dos empreendedores. Neste sentido, é razoável esperar que a existência de linhas de crédito promova o consumo e o investimento (ou poupança) destes agentes. Como consequência, espera-se um efeito positivo do acesso ao crédito no patrimônio dos poupadores e dos empreendedores.

A modalidade de crédito via hipotecas, em particular, interage com o patrimônio dos empreendedores também na direção oposta: o volume de crédito contratado via hipoteca depende positivamente do patrimônio do empreendedor. Empreendedores com maior patrimônio imóvel possuem maior capacidade de oferta de garantias ao credor e, portanto, possuem melhor acesso a crédito via hipoteca. Tal dependência positiva é bastante relevante quando o patrimônio do empreendedor é reduzido. Se o patrimônio não é suficiente para viabilizar o montante de crédito desejado pelo empreendedor, todo o patrimônio será usado como garantia para tomar emprestado o máximo possível de recursos. Se o patrimônio já é suficiente para viabilizar o montante de crédito desejado, aumentos no patrimônio não afetam o montante de crédito contratado via hipoteca, pelo menos por meio deste canal.

Como consequência da teoria exposta, é esperado observar nos dados históricos (i) correlação positiva entre o patrimônio do empreendedor e o volume de crédito via hipotecas por ele contratado e; (ii) redução desta correlação para níveis mais elevados de patrimônio. O efeito do patrimônio do empreendedor no volume de crédito acessado (doravante denominado efeito garantia) se manifestaria em correlação positiva e contemporânea: maior volume de crédito tomado pelos empreendedores com mais patrimônio no momento da contratação da hipoteca. Por outro lado, o efeito do acesso a hipotecas sobre o patrimônio do empreendedor (doravante denominado efeito patrimonial) se manifestaria em correlação positiva e intertemporal: maior patrimônio acumulado por empreendedores que acessaram crédito via hipoteca em períodos anteriores. 


\section{NOTAS APÊNDICE B}

'A este respeito ver Varian (2006) e Mas-Colell et al. (1995).

"O mercado automobilístico é o exemplo tipicamente utilizado para ilustrar incompletude de mercados. Akerlof (1978) utiliza este exemplo para motivar sua contribuição seminal para o desenvolvimento da literatura em Assimetria de Informação.

II' A este respeito, ver Mas-Collel et al. (1995) ou, por exemplo, a discussão introdutória de Hertzberg et al. (2018) e as referências citadas.

iv A este respeito, ver Mishkin (2007) e Diamond (1984, 1991, 1996). 